Article

\title{
New Method of Pulsed Electrodeposition of Nanostructure of ZnS Films
}

\author{
M.B. Dergacheva *, K.A. Urazov, G.M. Khussurova and K.A. Leontyeva \\ D.V. Sokolsky Institute of Fuels, Catalysis and Electrochemistry, Almaty 480100, Kazakhstan; \\ u_kazhm@mail.ru (K.A.U.); gulinur_k@bk.ru (G.M.K.); mayeva.kseniya@gmail.com (K.A.L.) \\ * Correspondence: m_dergacheva@mail.ru; Tel.: +7-727-291-58-08
}

Academic Editor: Massimo Innocenti

Received: 15 February 2016; Accepted: 17 March 2016; Published: 25 March 2016

\begin{abstract}
The voltammetry method of analysis is used to investigate the electrochemical behavior of zinc(II) and thiosulfate $\left(\mathrm{S}_{2} \mathrm{O}_{3}^{2-}\right)$ ions in acidic solutions and their electrochemical deposition onto glass coated with a conductive layer of tin oxide. It is found that electrodeposition conducted according to the two-electrode scheme using the pulse current generated by the industrial alternating current produces sound zinc sulfide deposits. Physical and chemical properties of obtained zinc sulfide films have been characterized by using scanning electron microscope and UV spectroscopy. The "cross-section" method is used to determine the thickness of zinc sulfide film, which is equal to $140-160 \mathrm{~nm}$. The obtained films have n-type conductivity.
\end{abstract}

Keywords: pulsed electrodeposition; thin film; ZnS; nanostructure

\section{Introduction}

Zinc sulphide is a non-toxic semiconductor of the II-VI group with a good band gap. It has excellent chemical resistance and thermal stability. The band gap of zinc sulphide is about $3.68 \mathrm{eV}$. This makes it a potential candidate to replace cadmium sulphide in the hetero transition of CdTe/CdS and CdS/CIGS solar cells. The band gap of ZnS $(3.68 \mathrm{eV})$ is larger than that of $\mathrm{CdS}(E=2.42 \mathrm{eV})$, which allows the use of $\mathrm{ZnS}$ as an optical window for $\mathrm{ZnS} / \mathrm{CdTe}$ or $\mathrm{ZnS} / \mathrm{CdS} / \mathrm{CdTe}$ cells. Zinc sulfide has an advantage in delivering high-energy photons in the absorbent material and reduces their interim loss, which improves the short-circuit current in solar cells. Possessing such characteristics, ZnS is widely used for manufacturing various optical devices and is of interest not only as an individual semiconductor material but also as one of the components in cascade solar cells [1-6].

Zinc sulphide is obtained mainly by chemical deposition from the gas phase [7], high-temperature pressing of zinc sulphide powder [8,9] and chemical deposition from aqueous solutions [10-12]. These techniques require a considerable amount of energy for the synthesis of zinc sulphide at high temperatures or special conditions of annealing.

This work has shown the possibility of electrodeposition of zinc sulphide films of specified stoichiometric composition from the aqueous solution. The advantages of technical electrochemistry and alternating power current are used. The composition and structure of zinc sulphide films obtained by the electrochemical method depending on the conditions of deposition are studied.

The aim of the work is to obtain thin films of zinc sulfide by using the industrial alternating current with $50 \mathrm{~Hz}$ power frequency according to the two-electrode scheme.

\section{Experimental Details}

The electrochemical behavior of $\mathrm{Zn}(\mathrm{II})$ and $\mathrm{S}_{2} \mathrm{O}_{3}^{2-}$ ions in aqueous solutions was investigated by using cyclic voltammetry. The electrochemical measurements were made in a three-electrode cell at room temperature using the universal potentiostat-galvanostat Gill AC (ACM Instruments, Cumbria, 
UK). The disk glass-carbon electrode $\left(S=0.07 \mathrm{~cm}^{2}\right)$ was used as a working electrode and Pt-wire as a contrary electrode. All potentials are shown with reference to $(\mathrm{Ag} / \mathrm{AgCl}) / \mathrm{KCl}$ sat) electrode. The potential sweep was made in the $0 \mathrm{~V}$ to $-2.0 \mathrm{~V}$ range in the cathodic direction (forward movement) and $-2.0 \mathrm{~V}$ to $+2.0 \mathrm{~V}$ in the anodic direct (backward movement) with $20 \mathrm{mV} / \mathrm{s}$ velocity.

Electrodeposition was performed in a two-electrode cell with stirring. The industrial alternating current was supplied with the frequency of $50 \mathrm{~Hz}$ by using the laboratory autotransformer, diode and 7.5 kilohm resistor. The average current density was $8 \mathrm{~mA} / \mathrm{cm}^{2}$ and was registered by B7-35voltmeter. Zinc sulfide films were electrodeposited onto the flourine doped tin oxide glass (FTO/glass) substrate for $45 \mathrm{~min}$ at $70{ }^{\circ} \mathrm{C}$ and $30^{\circ} \mathrm{C}$ from a solution containing $0.1 \mathrm{M}$ tartaric acid $\left(\mathrm{C}_{4} \mathrm{H}_{6} \mathrm{O}_{6}\right), 0.01 \mathrm{M}$ zinc sulfate $\left(\mathrm{ZnSO}_{4}\right), 0.01 \mathrm{M}$ sodium sulfite $\left(\mathrm{Na}_{2} \mathrm{SO}_{3}\right)$, and $0.01 \mathrm{M}$ sodium thiosulfate $\left(\mathrm{Na}_{2} \mathrm{~S}_{2} \mathrm{O}_{3}{ }^{*} \mathrm{H}_{2} \mathrm{O}\right)$, $\mathrm{pH}=2-2.05$. Sodium sulfite was used to prevent the formation of $\mathrm{SO}_{3}^{2-}$ and $\mathrm{S}$ due to disproportionate amount of thiosulfate ions. After electrodeposition, the films were rinsed in water, dried in air and annealed in air at $350^{\circ} \mathrm{C}$ for $30 \mathrm{~min}$.

Samples of films prepared under different conditions were investigated to determine the elemental composition and surface morphology by SEM (JSM-6610, JEOL Ltd., Tokyo, Japan) and AFM (JSPM-5200, JEOL Ltd., Tokyo, Japan).

The chemical composition of electrodeposited films was determined by X-ray attachment to electron microscopy (JSM-6610, JEOL Ltd., Tokyo, Japan).

Optical properties of the resulting samples were examined by the spectrometer Helios UV-Visible V7.00 (Helios, London, UK), with the possibility of registering the transmittance in the wavelength range from $190 \mathrm{~nm}$ to $1000 \mathrm{~nm}$. XRD measurement was made with device DRON-4 with iron irradiation (Bourevestnik, St. Petersburg, Russia).

\section{Results and Discussion}

There are basic electrochemical reactions of thiosulfate ion in acidic solutions [Reactions (1)-(3)] [13]. At high sodium thiosulfate concentrations, the process of disproportionate of $\mathrm{S}_{2} \mathrm{O}_{3}^{2-}$ to $\mathrm{S}$ and $\mathrm{SO}_{3}^{2-}$ is possible to achievethrough Reaction (2). The most likely anode reaction at high anode positive potentials is the reaction of thiosulfate ion oxidation according to Equation (3).

$$
\begin{gathered}
\mathrm{S}_{2} \mathrm{O}_{3}^{2-}+6 \mathrm{H}^{+}+4 \mathrm{e}^{-} \rightarrow 2 \mathrm{~S}+3 \mathrm{H}_{2} \mathrm{O} \\
\mathrm{S}_{2} \mathrm{O}_{3}^{2-} \rightarrow \mathrm{S}+\mathrm{SO}_{3}^{2-} \\
\mathrm{S}_{2} \mathrm{O}_{3}^{2-}+3 \mathrm{H}_{2} \mathrm{O} \rightarrow 2 \mathrm{H}_{2} \mathrm{SO}_{3}+2 \mathrm{H}^{+}+4 \mathrm{e}^{-}
\end{gathered}
$$

Zinc ions in simple salt solutions are involved in reduction-oxidation reactions with the transfer of two electrons [Reactions (4) and (5)].

$$
\begin{aligned}
& \mathrm{Zn}(\mathrm{II})+2 \mathrm{e}^{-} \rightarrow \mathrm{Zn}^{0} \\
& \mathrm{Zn}^{0}-2 \mathrm{e}^{-} \rightarrow \mathrm{Zn}(\mathrm{II})
\end{aligned}
$$

Figure 1 compares cyclic voltammetry curves of reduction on a glass-carbon electrode from the electrolyte. On the simultaneous electro-reduction of zinc and thiosulfate ions from a simple salt solution in the cathode region (Figure 1a), one observes two peaks of reduction current in the potential range (B): (1) $-1.15 \div-1.45$ (peak B) corresponds to the process of $\mathrm{Zn}$ (II) reduction to $\mathrm{Zn}^{0}$, just as in Figure $1 \mathrm{~b} ;(2)-1.45 \div-1.7$ (peak $\mathrm{C}$ ) corresponds to the process of formation of zinc sulfide compounds according to Reaction (6).

$$
\mathrm{Zn}+\mathrm{S}+2 \mathrm{e}^{-} \rightarrow \mathrm{ZnS}
$$



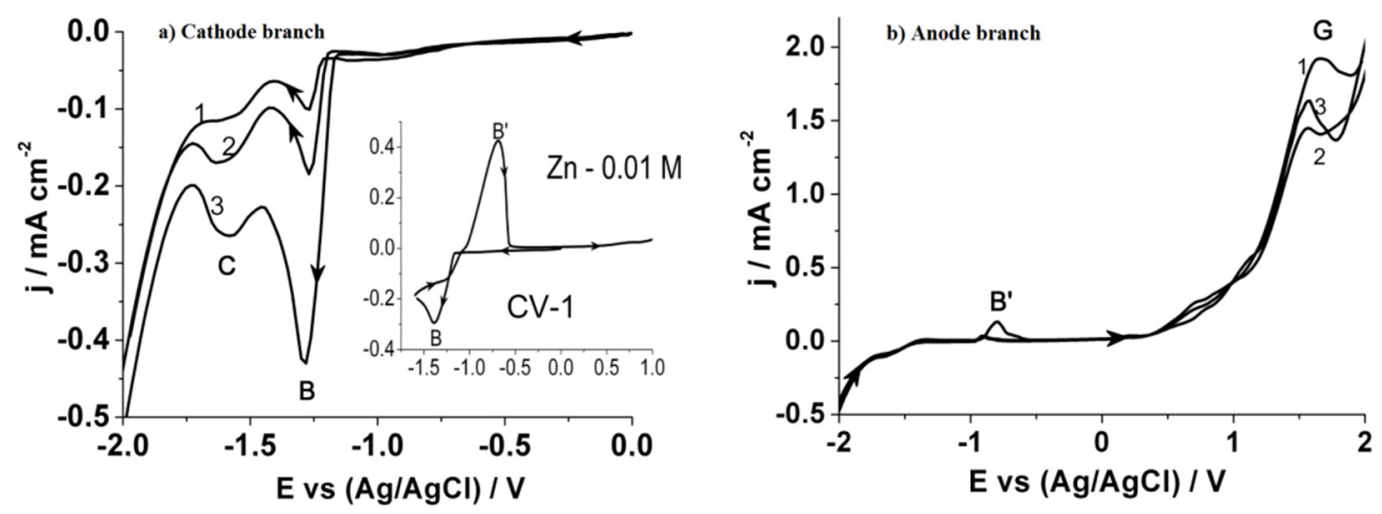

Figure 1. (a) Cyclic voltammetry curves of reduction-oxidation of $\mathrm{Zn}(\mathrm{II})$; (b) Cyclic voltammetry curves of reduction-oxidation of $\mathrm{S}_{2} \mathrm{O}_{3}^{2-}$ ions. $\mathrm{C}_{\left(\mathrm{Na}_{2} \mathrm{~S}_{2} \mathrm{O}_{3}\right)}=0.02 \mathrm{M} ; \mathrm{C}_{\left(\mathrm{ZnSO}_{4}\right)}: 1-0.01,2-0.02,3-0.03 \mathrm{M}(\mathrm{pH}=5.0)$; $(\mathrm{CV}-1) \mathrm{C}_{\mathrm{ZnSO}_{4}}=0.01 \mathrm{M}$.

In the case of backward potential sweep, the anodic part of the potentiodynamic curve (Figure 1b) shows an additional oxidation peak $\left(\mathrm{B}^{\prime}\right)$ with a maximum at -0.75 potential, according to Reaction (4). It appears when the concentration of $\mathrm{Zn}$ (II) ions exceeds that of sodium thiosulfate, and the elemental zinc, which has not reacted with sulphur on the electrode, starts to be oxidized. The oxidation of thiosulfate ions begins at high positive potentials [Reaction (3)] (peak G).

Based on the voltammetry analysis, it is concluded that zinc sulphide deposition can only be implemented while maintaining a strongly negative constant potential. To avoid this, the method of electrodeposition according to the two-electrode scheme using pulsed current $\left(8 \mathrm{~mA} / \mathrm{cm}^{2}\right)$ is offered.

Table 1 lists the results of the elemental analysis of zinc sulfide films obtained at $70{ }^{\circ} \mathrm{C}$ by such a process as an average of three determinations at different points of the surface. Deviations from the average value are of different magnitudes. It is found that electrodeposition by pulse current makes it possible to obtain films with the composition close to stoichiometric (Tables 1 and 2). However, it has been revealed that the results depend greatly on the deposition temperature.

Table 1. Chemical composition (at.\%) of zinc sulfide films electrodeposited at $70{ }^{\circ} \mathrm{C}$.

\begin{tabular}{ccc}
\hline \multirow{2}{*}{ No. } & \multicolumn{2}{c}{ Content, at.\% } \\
\cline { 2 - 3 } & Zn & S \\
\hline 1 & 53.22 & 46.78 \\
2 & 50.11 & 49.89 \\
3 & 60.80 & 39.20 \\
4 & 53.96 & 46.04 \\
\hline \multicolumn{3}{c}{$\Delta$ (average deviation) $= \pm 6.68$} \\
\hline
\end{tabular}

Table 2. Chemical composition (at.\%) of zinc sulfide films electrodeposited at $30^{\circ} \mathrm{C}$.

\begin{tabular}{ccccc}
\hline \multirow{2}{*}{ Components } & \multicolumn{4}{c}{ Content, at.\% } \\
\cline { 2 - 5 } & $\mathbf{1}$ & $\mathbf{2}$ & $\mathbf{3}$ & $\mathbf{4}$ \\
\hline $\mathrm{Zn}$ & 48.8 & 49.55 & 49.11 & 48.05 \\
$\mathrm{~S}$ & 51.2 & 50.75 & 50.89 & 51.95 \\
\hline \multicolumn{4}{c}{$\Delta$ (average deviation) $= \pm 0.75$} \\
\hline
\end{tabular}

At $70{ }^{\circ} \mathrm{C}$, there is a considerable scatter in the data, and the average deviations in some cases are greater than \pm 6.68 at.\%. This is due to the formation of colloidal sulfur in the electrolyte at high temperatures and prolonged electrolysis, which is also involved in the process. Therefore, further 
research has been carried out at $30^{\circ} \mathrm{C}$ when the electrolyte remains transparent for a long time. Table 2 lists the data on the elemental analysis of $\mathrm{ZnS}$ films obtained at these temperatures. The deviation from average values does not exceed \pm 0.75 at. $\%$. In this case, there is a slight increase in the sulfur content with respect to the $\mathrm{Zn}: \mathrm{S}=1: 1$ ratio.

Figure $2 a, b$ show the micrographs (magnification 20,000 $\times$ ) of the film surface. Data on the study of the surface of annealed films show significant densification of grains and formation of ordered structure resulting from the annealing of zinc sulfide films.
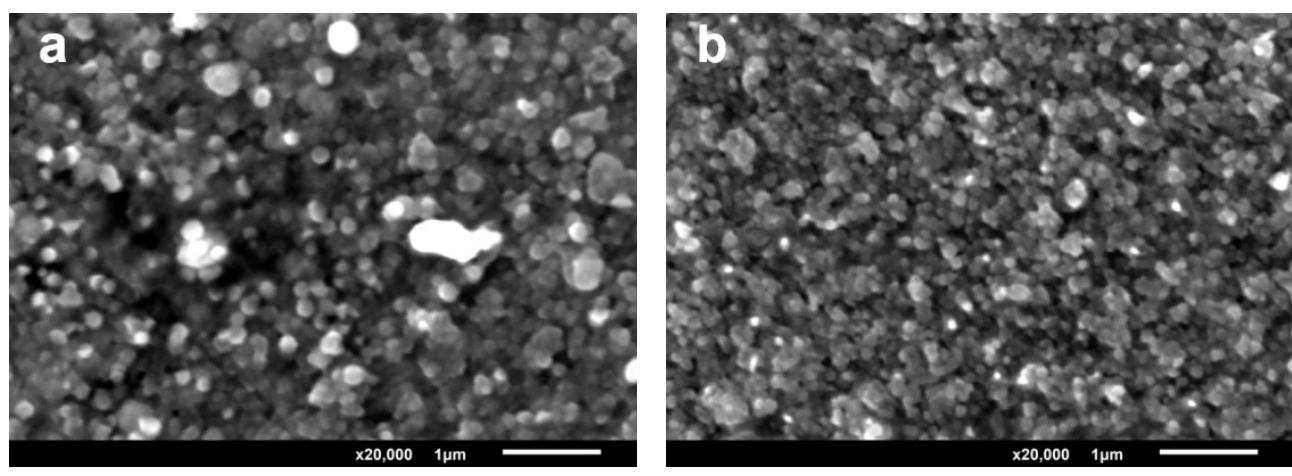

Figure 2. Micrographs of $\mathrm{ZnS}$ films electrodeposited at different temperatures: (a) $\mathrm{T}=70{ }^{\circ} \mathrm{C}$; (b) $\mathrm{T}=30^{\circ} \mathrm{C}$.

During pulsed deposition at $70^{\circ} \mathrm{C}$, the coating is uniform but has micro cracks which increase on annealing. During pulse-current deposition at $30^{\circ} \mathrm{C}$ (Figure $2 \mathrm{~b}$ ), the surface coating is dense and one observes smaller $\mathrm{ZnS}$ crystals with the sizes of 100 nanometers or less.

The thickness and optical properties were investigated for the films obtained at $30{ }^{\circ} \mathrm{C}$.

The film thickness was determined by the "cross-section" method using JEOL IB-09010CP (JEOL Ltd., Tokyo, Japan). As shown on the micrographs (Figure 3a), the thickness of zinc sulfide films is 140-160 nm.
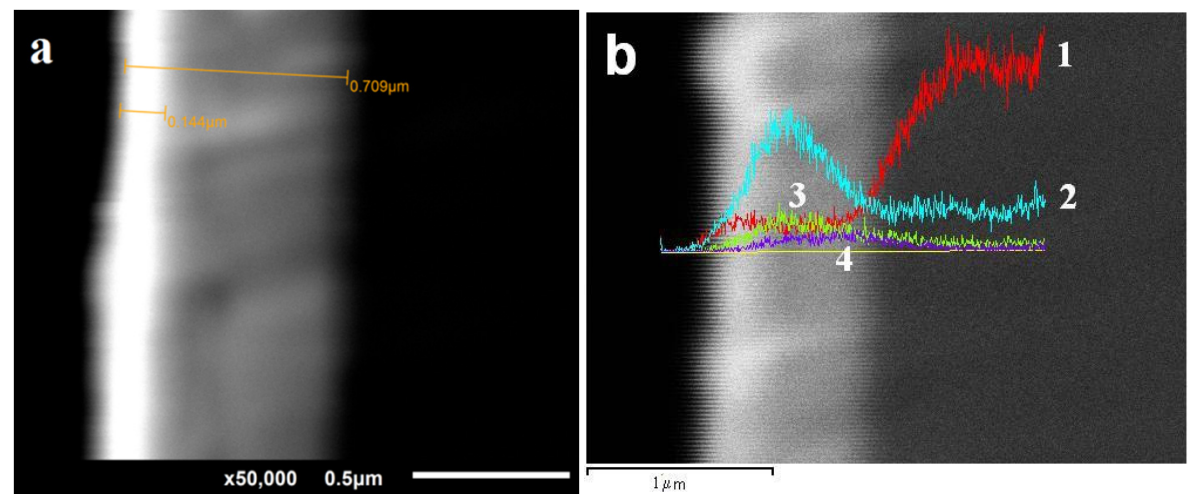

Figure 3. Micrographs of ZnS film "cross-section": (a) thickness in $\mu \mathrm{m}$; (b) distribution of composition over the film thickness in wt. \%. 1-silicon, 2-zinc, 3-sulphur, 4-tin.

The total thickness of the coating together with the $\mathrm{SnO}_{2}$ conductive layer is less than $1 \mu \mathrm{m}$. Figure $3 b$ shows the distribution of elements over the film thickness. It is seen that the maximum of sulfur and zinc falls on the deposited part of the film. The substrate of the conductive glass coating exhibits a uniform distribution of tin, and silicon is identified in the glass as the main component. The n-type conductivity for all $\mathrm{ZnS}$ films is determined by the method using a thermal probe.

The surface morphology has been characterized by using the atom force microscope JSPM-5200 (JEOL Ltd., Tokyo, Japan) and it is shown in Figure 4a. 


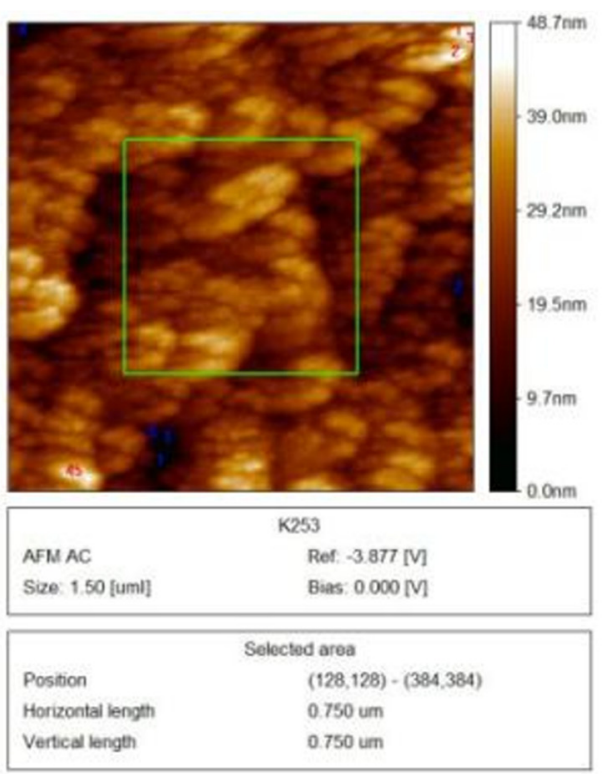

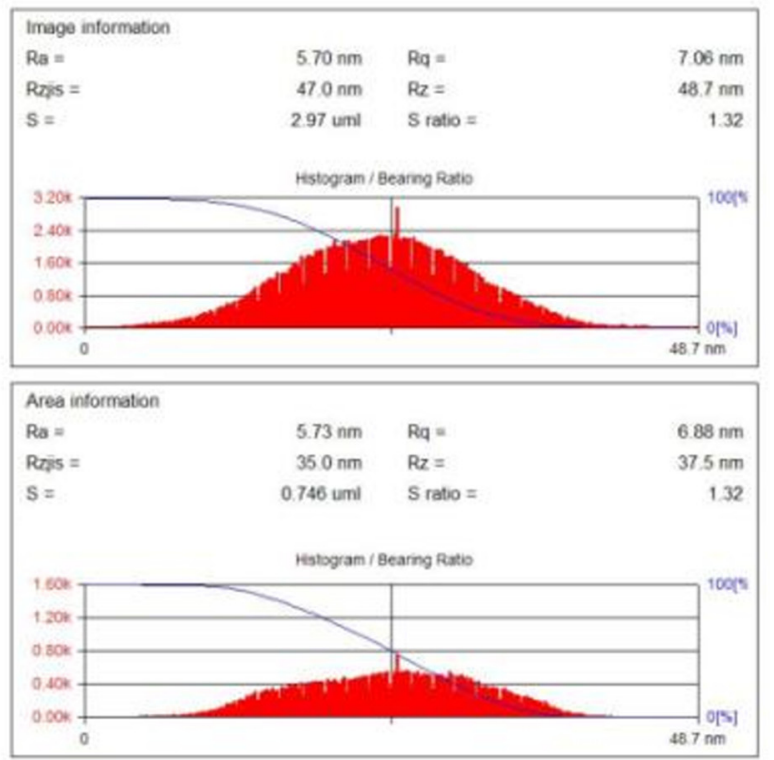

(a)

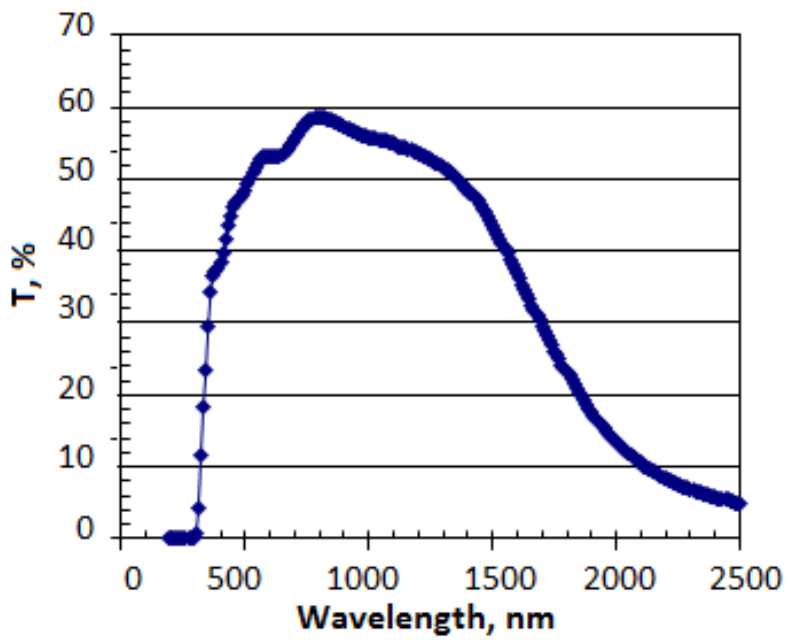

(b)

Figure 4. (a) AFM image of surface and distribution of particle sizes; (b) transmittance spectra of ZnS films.

The studies show that the surface is uniformly coated with fine $\mathrm{ZnS}$ particles. The smallest $\mathrm{ZnS}$ particle has a $5.7 \mathrm{~nm}$ diameter, and its height is $39 \mathrm{~nm}$. Large $\mathrm{ZnS}$ particles are composed of smaller ones, their maximum diameter being less than $115 \mathrm{~nm}$. The substrate topography of $\mathrm{ZnS} / \mathrm{F}: \mathrm{SnO}_{2} / \mathrm{glass}$ has been studied using a three-dimensional (3D) image. The film thickness is $200 \mathrm{~nm}$. Figure $4 \mathrm{~b}$ shows that $\mathrm{ZnS}$ films have high transmittance in the 400-2000 nm wavelength range and cover the entire visible spectrum and the near-infrared region. The absorption band edge corresponds to a $320 \mathrm{~nm}$ wavelength. Based on the transmittance spectra, the band gap of $\mathrm{ZnS}$ films is determined to be $3.8 \mathrm{eV}$.

The electrodeposited films have n-type conductivity. This shows great possibilities of using electrodeposited zinc sulfide films as an optical window in the cascade of thin-film solar cells.

The structure of ZnS film after annealing was determined by using X-ray analysis. In Figure 5, the X-ray spectra of electrodeposited ZnS film are shown and theyindicate a phase of ZnS (ASTM 10-434). The film is so thin that the reflexes of the FTO substrate at the X-ray spectracan be seen. 


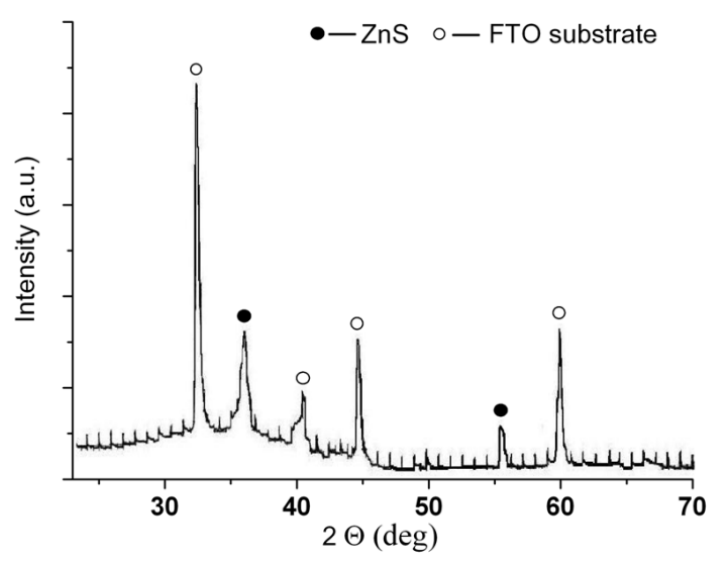

Figure 5. X-ray spectra of electrodeposited ZnS film.

\section{Conclusions}

The use of industrial alternating current with $50 \mathrm{~Hz}$ frequency and electrodeposition carried out at $30{ }^{\circ} \mathrm{C}$ according to the two-electrode scheme have made it possible to obtain $\mathrm{ZnS}$ films of stoichiometric composition that have good optical and electronic properties.

Acknowledgments: This work was supported by Ministry of Education and Science, Kazakhstan (Grant No. 0200/GF4).

Author Contributions: M.B. Dergacheva and K.A. Urazov conceived and designed the experiments; K.A. Urazov performed the experiments; G.M. Khussurova and K.A. Leontyeva analyzed the data; M.B. Dergacheva and K.A. Urazov wrote the paper.

Conflicts of Interest: The authors declare no conflict of interest.

\section{References}

1. Chopra, K.; Das, S. Thin Film Solar Cells; Plenum Press: New York, NY, USA, 1983.

2. Dharmadasa, I.M. Advances in Thin Film Solar Cells; CRC Press: New York, NY, USA, 2012.

3. Koutsa, T.; Minkina, G. Sovremenye problemi poluprovodnikov v energetike; Mir: Moscow, Russia, 1988. (In Russian)

4. Echendu, O.K.; Weerasinghe, A.R.; Diso, D.G.; Fauzi, F.; Dharmadasa, I.M. Characterization of n-type and p-type ZnS thin layers grown by an electrochemical method. J. Electron. Mater. 2013, 42, 692-700. [CrossRef]

5. Kashani, H. Production and evaluation of $\mathrm{ZnS}$ thin films by the MOCVD technique as alpha-particle detectors. Thin Solid Films 1996, 288, 50-56. [CrossRef]

6. Porada, Z.; Schabowka, E. Surface electrical conductivity in $\mathrm{ZnS}(\mathrm{Cu}, \mathrm{Cl}, \mathrm{Mn})$ thin films. Thin Solid Films 1986, 145, 75-79. [CrossRef]

7. Devyatih, G.G.; Gavrishuk, E.M.; Ikonnikov, V.B.; Yashina, E.V.; Dianov, E.M. Sposob poluchenya polykristallichekogo sulfide cinka. RU Patent 2221906, 2003. (In Russian).

8. Shibata, K. Optical Component, Zinc Sulfide Sintered Compact and Fabricating Method Thereof. US Patent 6,111,689, 28 August 2000.

9. Yazici, A.N.; Oztas, M.; Bedir, M. Effect of sample producing conditions on the thermo luminescence properties of $\mathrm{ZnS}$ thin films developed by spray pyrolysis method. J. Lumin. 2003, 104, 115-122. [CrossRef]

10. Kassim, A.; Razak, N.; Min, H.S. Atomic force microscopy studies of zinc sulphide thin films. Int. J. Adv. Eng. Sci. Technol. 2011, 7, 169-172.

11. Nabiyony, G.; Sahraei, R.; Toghiany, M.; Majles Ara, M.H.; Hedayati, K. Preparation and characterization of nanostructured $\mathrm{ZnS}$ thin films grown on glass and n-type Si substrates using a new chemical bath deposition technique. Rev. Adv. Mater. Sci. 2011, 27, 52-57. 
12. Miyawaki, T.; Ichimura, M. Fabrication of ZnS thin films by an improved photochemical deposition method and application to ZnS/SnS heterojunction cells. Mater. Lett. 2007, 61, 4683-4686. [CrossRef]

13. Zhdanov, I. Sulfur. In Encyclopedia of Electrochemistry of the Elements; Bard, A.J., Ed.; Marcel Dekker: New York, NY, USA, 1975; Volume 4.

(c)

(C) 2016 by the authors; licensee MDPI, Basel, Switzerland. This article is an open access article distributed under the terms and conditions of the Creative Commons by Attribution (CC-BY) license (http:/ / creativecommons.org/licenses/by/4.0/). 